\title{
INDUSTRIAL CLUSTERING AND GLOBAL VALUE CHAINS \\ IN CENTRAL AND EASTERN EUROPE: ROLE OF MULTINATIONAL ENTERPRISES IN INDUSTRIAL UPGRADING
}

\author{
Yusaf H. Akbar, Sonia Ferencikova *
}

\begin{abstract}
:
The authors are attempting to draw together existing literature on the governance of GVCs; research on host country "spillovers" as a consequence of MNE activity and the broader cluster and innovation literature. While cluster research had done important work in identifying and operationalizing the necessary conditions for cluster formation, it had relatively ignored the global-local linkage brought by the presence of MNEs. The "spillover" literature has identified in theory numerous benefits of MNE presence in host countries. There was relatively little empirical work done in CEE to discover if these benefits actually exist. Neither literature had focused on how MNEs govern their GVCs. Thus bringing these sources together presents an important opportunity for international business.

The authors find that in the Slovak case the industrial clusters among the firms surveyed were not much functional. On a strategic level, there appears to be little evidence of cooperation in areas of marketing, export promotion or investment. This is especially of concern in sectors such as automotive where cooperative strategies among suppliers could offer significant benefits.
\end{abstract}

Keywords: transformation in Central and Eastern Europe, foreign direct investment, industrial clustering, multinational enterprise

JEL Classification: F21, F23

\section{Introduction}

Does the insertion of local clusters into the global value chains of multinational enterprises (MNEs) enhance or undermine the ability of the cluster to successfully pursue upgrading strategies? What is the impact of interactions between clusters and global value chains (GVCs) on economic development? Palpacuer and Parisotto (2003: 98) argue that there is a "recognition that complementary analytical frameworks should be combined in novel forms to analyse the interplay between local and global forces, and, ultimately, devise new attitude to employment and development policies".

* Yusaf Akbar, School of Business, Southern New Hampshire University, 2500 N. River Road, Manchester, NH 03106 (y.akbar@snhu.edu); Sonia Ferencikova, Department of International Business, University of Economics, Dolnozemska 1, SK - 85235 Bratislava (ferencik@dec.euba.sk).

Partial funding for this research was provided to Sonia Ferencikova: Grant VEGA/1/2638/05,

Strategies of multinational companies on the CEE markets: trends in the last decade and their future expected development. 
Scott (1996) argues that economic globalization reinforces the factors that drive local competitiveness. Gereffi (1999) suggests that internationalization of activities is crucial to the ability of local firms to develop new competencies and upgrade their production. By contrast Humphrey and Schmitz (2002) claim that the success of upgrading is not given by virtue of being open to international trade. Rather, success is closely related to the nature of the relationship between local clusters and the MNEs with which they cooperate. Pavlinek (2003) posits that the fate of local clusters is intimately connected to the degree of embeddedness of the MNE in the local economy and the cluster specifically.

This paper empirically examines these competing perspectives by focusing on emerging industrial clusters in Central and East Europe (CEE). The CEE region represents fertile empirical ground because the region is developing local clusters in industries that produce goods and services that are traded globally and demonstrate increasing levels of global market concentration in the hands of large MNEs. Examples of these sectors include automobile assembly, electronics and information technology services. Interestingly, the diversity of the firms in the local clusters, ranging from local SMEs to MNE supplier companies also raises important issues of the feasibility and desirability of local cluster development more generally. Of particular importance has been the emphasis placed on these clusters by public policymakers in the context of economic development for the CEE region.

\section{Conceptual Starting Point}

In an interdependent world economy, in which competition for market share in a gamut of industries has intensified, the development prospects of multinational companies are commonly focused on the integration of their activities into a transnational value of chain of activities, i.e. a global value chain (GVC). At the same, there is also an increased recognition that a salient aspect of technological and efficiency related development of companies occurs on a local, embedded and clustered basis.

These phenomena are taking place against a backdrop in which sustainable economic development for societies is a function of a complex interplay of public and private policies and strategies and where the impact of economic activity occurs on interrelated local, regional and transnational spaces. An important task is analysing future trajectories for economic development that examine these dimensions. For public policy, academic inquiry and business strategy, understanding the conditions under which the exigencies of economic development of political economies and the strategic objectives of multinational enterprises can be matched represents one of the great challenges in coming years.

In the context of economic transformation in CEE, considerable hope has been expressed that the development of local industrial clusters linked to the international economy through relationships with MNEs will provide the necessary basis for future economic development.

From the perspective of MNE strategy inserting local clusters in their global value chains also represents an important opportunity to enhance competitiveness and efficiency by leveraging the knowledge resources developed by local clusters especially in the context of CEE.

\section{Background Literature Survey}

The international business academic area relies upon the leveraging of a multidisciplinary range of approaches. In this tradition, our paper exploits a multidisciplinary approach 
drawing on three related areas of literature. We draw links between industrial clustering, foreign direct investment in CEE and the governance of global value chains.

\section{(a) Industrial Clustering}

First is the work on the development of industrial clusters especially from the "new economic geography' and regional studies literature ${ }^{1}$. As early as the work of Marshall (1890), there has been an awareness of the importance of geographical proximity in determining the location of industrial activity. Marshall argued that clusters develop as a consequence of three factors (a) the presence of a skilled local labour market, (b) key inputs from suppliers and (c) rapid know-how transfer between firms leading to technological spillover. Similar arguments have been echoed in $\operatorname{Krugman}(1991,1995)$ and Krugman and Venables (1995). Econometric evidence from Audretsch and Feldman (1996) also suggests that innovative activity - at the core of cluster development - tends to cluster due to technological and knowledge-based spillovers.

The industrial clustering work of Porter (1990, 1998 and 2003) is regarded as seminal. As a corollary to his "diamond" framework, Porter argued that clusters developed and were sustained by a focus on four key variables (demanding customers, related and supporting industries, factor endowments and firm structure and rivalry). Porter thus believed that clustering was largely an organic bottom-up process driven by the market. Further support for Porter's findings come from research on the importance of social networking as central to cluster development (Pouder and St. John 1996, Saxenian 1994).

Recent work of regional studies (e.g. Bathelt et al. 2002; Breschi and Malerba 2001; Hendry et al. 2000; Kenney 2000; Malmberg and Massell 2002; Martin and Sunley 2003; Sturgeon 2003; Wolfe and Gertler 2004) has also been crucial in the development of concepts of industrial clustering and its relationship to public policy in particular. On both a conceptual and methodological level, this literature offers a series of conceptual criteria and qualitative approaches. Another related category is the work on the development of global value chains. As for the situation in the CEE region, only few works can be found: for example Zizka (2006) studied the situation in the Czech Republic and concluded that mainly economically weak companies, micro- and small enterprises are interested to participate in clusters.

One of the central outcomes of this literature is that in imperfectly competitive markets and in the presence of both positive and negative externalities, economic activity is likely to be spatially distributed in an uneven fashion. Industries will tend to cluster in response to agglomeration economies - where cost savings and efficiencies from production emerge as a consequence of proximity. Examples of these agglomeration economies include access to a local skilled labour force, existing physical and technological infrastructure, links between universities and industrial activities. Agglomeration economies are especially important in industries where innovation is a central factor in the success of industrial activity. Firms in related industries will be attracted by the innovative activities of other firms through learning spillovers between them. Moreover the extent to which a network of communication and interaction between the firms in the cluster exists will play a large role in the sustainability of the cluster.

1 This paper uses the term 'Regional Studies' in order to avoid confusion between economists who call their work 'economic geography' and those of economic geographers who fall into the regional studies category. As will be emphasized in this project, the multidisciplinary emphasis of regional studies is a considerable strength when the local-global linkage issue is examined. 
Due this finding, there is a debate in this literature with regard to the extent in which public policy can provide successful support for clustering by local, regional, national and international policymakers. This debate further examines the implications for public policy of the clustering-global value chain link in the CEE region.

\section{(b) Foreign Direct Investment and Transformation in Central and East Europe}

Related to the clustering research is the literature on the role played by multinational enterprises in the economic development of the CEE region especially through FDI (e.g. Akbar 2003, Akbar et al. 2006, Akbar and McBride 2004, Antal-Mokos 1998; Bevan and Estrin 2000; Bridgewater et al. 1995; Brouthers et al. 1998; Estrin et al 1997; Estrin et al 2000; Fabry 2001; Hunya 2000a, 2000b; Konings 2001; Meyer 1998; Plikynas and Akbar 2006, Pye 1998; Zemplinerova 1998). First, causes of FDI in the region are interrelated to a number of factors including (but not limited to) availability of low-cost resources such as skilled labour; relative proximity to a major market for the MNEs; the role of public policy, e.g. privatization in attracting FDI through acquisitions of privatized enterprises or the importance of fiscal incentives and free trade zones; the salience of regional integration such as EU membership and political stability. Second, the literature suggests that the impact of FDI on the economic development of the region is uneven. While some of this literature suggests that FDI has had a largely beneficial role in the region, the spatial distribution of these benefits has led to certain sectors and regions prospering and others underperforming. Third, it is possible to partially explain the uneven nature of the benefits of FDI and its contribution to economic growth to the degree to which MNE activities have led to 'spillover' into the local economy. The extent in which countries have been able to encourage and foster spillover such as managerial know-how or technology transfer has arguably helped explain the superior longer-term performance of their economies. This latter claim is central to the upgrading possibilities for local firms and clusters.

The extent in which a policy of economic transformation was pursued; the political and social resistance to economic changes; the degree of transparency of that transformation process all link to FDI outcomes. For example, some CEE countries pursued open and reasonably transparent policies of transformation. There is a link between this and the relatively higher levels of FDI in these countries when compared to countries whose transformation processes were less transparent, more faltering and struggled to come to terms with the distributional consequences of those changes. In some extreme cases, the transformation process was actually resisted by governments as in Belarus.

An interesting illustration of a country that at first resisted transformation and then embraced it is Slovakia - the focus of our empirical work. The Meciar government in Slovakia wanted to create "domestic capitalists" by keeping companies in Slovak private ownership or in the state hands (dubbed strategic enterprises). It was difficult for a foreign company to enter the privatization during the Meciar period, but the presence of foreign investors via greenfield or brownfield was not hindered by any rules per se. Of course, bureaucracy was an issue, but it was typical for all the governments and all CEE countries and not a specifically Slovak problem. Also, joint ventures and alliances were at that time created with those private owners who already privatized something before. Also, the economy was relatively liberalized, not closed - the economic development received high ranking in a 1997 EU Commission report on Slovakia, but the government was criticized primarily for the failure to create a functioning democracy. 


\section{(c) Global Value Chain Governance}

There are clearly complex interrelationships between the pursuit of competitive advantage of MNEs and local economic development. While there is substantial research on both the nature of industrial clustering on the one hand and the development of value chains on the other, as Humphrey and Schmitz (2000:4) argue, relatively little work in the respective literature was done to systematically and rigorously conceptualize the importance of the interactions between clusters and global value chains (GVCs).

Bain and Gereffi (2001) develop an analysis of "Global Commodity Chains" $(\mathrm{GCCs})^{2}$. They differentiate between global producer chains and global buyer chains. Global producer chains are based around the strategy of a large MNE that coordinates the complex assembly of a final product e.g. the automotive or electronics sectors. Global buyer chains are built around the exigencies of large-scale marketer or retail companies. In this case, the firms in the GCC carry out the production for sale and distribution by a company that does not directly involve itself at all with assembly or production. These MNEs specialize in branding, design and marketing.

They argue that the success of upgrading for companies in GCCs is a function of their relationship to the "lead supplier". Through an illustration of the US/Mexican textile industry that they characterize as being a global buyer GCC, they demonstrate that where local companies can control an increasingly broad range of activities in the GCC, they are able to upgrade from being textile component manufacturers towards becoming "full product" producers for US companies. As the firm rises up the GCC, they eventually become the "lead supplier". This privileged position in the GCC can lead to these firms emerging as final product marketers and branding companies.

Palpacuer and Parisotto (2003) refer to global enterprise networks (GENs), again akin to GVCs in their conceptual analysis of the upgrading prospects for local firms. They claim that the prospects for local upgrading are hindered by two main factors. First, they argue that in the most profitable, service-related sectors, barriers to entry are rising due to increased protection for intellectual property and intangible assets of MNEs. Second, the benefits of participation in GENs and the potential for upgrading are unevenly distributed among local firms. Firms upstream in the GEN tend to be less successful at upgrading than the 'lead local firms' who work closely with the MNE.

As the history of economic development of countries suggest, the ability of local firms to upgrade their activities is crucial to the economic fortunes of countries. Examples of successful upgrading include the so-called newly industrializing countries (NICs) of Asia such as Taiwan and South Korea. Of note is the transformation of their activities from the pursuit of process upgrading through product upgrading to functional upgrading. ${ }^{4}$ In this context, does the nature of the insertion of local clusters in GVC affect the ability to follow this upgrading path?

2 The term GCC is arguably too narrow since much international trade takes place in intangible, non-commodity products, thus the term Global Value Chain (GVC) is used in this proposal when not referring to the work of Gereffi.

3 "Full product" manufacturing involves the entire production of a textile garment often on behalf of a global marketer company such as Nike or Reebok.

4 Process upgrading emphasizes the more efficient production of goods and services; product upgrading relates to the ability to produce more sophisticated product lines (leading to higher unit values) and functional upgrading. 


\section{Research Propositions}

Based on the literature review, we identify two testable propositions:

Proposition 1: Successful local cluster upgrading (i.e. the ability to develop international competitiveness) depends on the nature of insertion of local clusters into GVCs.

We can identify different kinds of insertion of clusters into GVCs as a function of the degree of control exerted by the MNE. Firms create different contractual relationships as a function of the degree of risk involved in an economic transaction. Where buyers need to ensure certain quality levels of inputs or where suppliers cannot be relied upon to provide such quality without the cooperation and supervision of buyers then transactions become increasingly controlled by the buyer. Williamson (1979) identified three kinds of contractual relationships between firms. First, market relationships where buyers acquire their inputs through an open, non-exclusive market-based purchase. Second, network relationships where suppliers and buyers coordinate their activities through a close cooperation of their activities. Third, Williamson considered vertical integration in which buyers exercised full or partial ownership of suppliers thereby exerting considerable control over the activities of the suppliers. Vertical integration can vary as a function of the degree of control exercised by the buyer firms.

Sako's (1992) seminal work on trust in buyer-supplier relations in the UK circuit board industry suggested two 'ideal types' of contracting relationships: "Arm's Length Contractual Relations" (ACR) and "Obligational Contractual Relations" (OCR). The former is where firm interaction is characterized by a lack of trust between parties; mutual interdependence is low; formal contracts exist and there is a lack of technology and knowledge sharing. By contrast, OCR exhibit high levels of trust; interaction and sharing of knowledge and technology between contracting parties.

Humphrey and Schmitz (2002) refer to relationships as "arms length", "quasi hierarchical", "hierarchical" and "network relations". The more "hierarchical control' exerted by the lead supplier or MNE, the less likely that local clusters can upgrade according to Humphrey and Schmitz. Table 1 below summarizes these three related characterizations:

Table 1

Nature of Contractual Relationships between Local Cluster and MNE

\begin{tabular}{|l|l|l|}
\hline Williamson & Sako & Humphrey and Schmitz \\
\hline Arms Length & ACR & Arms Length \\
\hline Network relations & OCR & Reciprocal Dependence \\
\hline Vertical Integration & & Quasi-hierarchy, Hierarchy \\
\hline
\end{tabular}

Source: authors' own

Proposition 2: As direct control of cluster activities by MNEs increases, the ability for local clusters to upgrade weakens.

GVCs exist in part to allow MNEs to coordinate and control their activities to maximize efficiency and access key resources across countries. Strategically MNEs use GVCs to leverage their core competences and capabilities, sub-contracting activities which can be more efficiently carried out by other firms in the GVC. As MNEs subcontract in the GVC, they also need to have mechanisms in place to control the quality of activities of the subcontractor companies. This can take numerous forms: discouraging sub-contractor companies from having relationships with competing MNEs or restricting the flow of proprietary knowledge possessed by the MNE to prevent losses of competitive advantage. On the other hand, it can also include the sharing of knowledge to allow the 
subcontracting companies to improve their efficiency too, but only to the extent that it does not threaten the MNEs market position. There is a threat to MNEs that if their suppliers acquire new competences acquired through the GVC that directly compete with the MNE, this leads to the undermining of the MNE's competitive advantage. ${ }^{5}$

\section{Empirical Methodology}

A priori analysis suggests that the automotive and electronics sectors in CEE would be worth considering as case studies of global producer chains since they possess many of the characteristics of GVC-cluster relationships that are examined in this study. Moreover, Central European public policymakers have emphasized the importance of these sectors in the development of their economies.

The difficulties of acquiring reliable data at the firm and industry level in CEE economies require the generation of data sets for the purposes of this research. Since the process of transition began in 1989, there is at most around 15 years of data available to researchers. It is thus statistically questionable whether macro-level panel data analyses can be validated within bounds of statistical confidence. ${ }^{6}$ The issue is especially acute at the firm-level. Many of the variables influencing patterns of FDI and industrial clustering are not available in published enterprise-level data sets. Case-study and questionnaire-based research can best identify the relevant variables and their causal relationships between them. Our paper examines the Slovak automotive sector based on a questionnaire sent to Slovak parts suppliers.

The automotive industry is an important sector for the Slovak economy. It employed 55,000 people in 2005 in both assemblers and suppliers. It contributes to $26.5 \%$ of total Slovak industrial production, $30 \%$ of Slovak exports and $20 \%$ of total Slovak sales. ${ }^{7}$ The biggest player is Volkswagen that has been active in Slovakia since 1991. The total production of Volkswagen in 2005 accounted for 218,000 automobiles and in 2006 it was 236,000. The brands like VW Passat, Golf, Polo and recently SUV Toureg, Porsche Cayenne and Audi Q 7 were assembled in Bratislava. The new Peugeot Citroen plant has just started the first operation in 2006 in city of Trnava when it assembled 51,000 cars - the projected numbers for this plant is 300,000 assembled cars yearly from 2008. Kia Motors is building another plant in Zilina that produced first 5,000 cars in 2006 and it is supposed to produce 300,000 cars by 2008 as well. All together the projected numbers for 2008 for Slovakia are around 840,000 cars what will bring Slovakia among the top car producers in the world, certainly the biggest one producer per capita since Slovakia has about 5.2 million inhabitants. The activity of these three companies caused a big pull effect and the arrival of many first-tiers suppliers in Slovakia, e.g. Johnsons Control, Delphi, Ford Getrag, Visteon, Dana, Hella, Continental, Kuester, Faurecia, Tower Automotive occurred.

Our results are based on 34 (from a total of 120) companies that fully completed the questionnaire (i.e. the response rate was 28 per cent). The results, in detail below, reveal support both for and against our two propositions.

5 This can be referred to as the shift of a local cluster from Original Equipment Manufacturer (OEM) to Own Brand Manufacturer (OBM).

6 That does not imply, however, that macro-level panel data analysis is completely invalid.

7 Slovak Economics Ministry statistics 


\section{Company Sample}

The companies chosen for our questionnaire are all second-tier suppliers in the automotive value-chain. The principle reason why second-tier supplies are important for our study is that they have the potential to emerge as first-tier suppliers yet the nature of their insertion into the GVC and their relations with each other in the geographical cluster may be determining factors in their ability to upgrade industrially.

The companies range from newly created businesses since the transition process began to formerly state-owned enterprises. Our sample is not large enough to draw inferences based on the ownership and management of the companies. These companies are typically contracted to work on behalf of the foreign first-tier suppliers based in Slovakia or abroad. In turn, the first tier suppliers (mentioned above) work with the assemblers that are household names in the world automotive industry such as Volkswagen, Peugeot-Citroen and Kia Automotive.

Given the relatively small size of Slovakia in geographical terms, all the firms surveyed are closely located to each other. Thus in a basic geographical sense, the firms are 'clustered'. While spatial proximity may qualify the firms as a cluster, we were also interested in examining several of the functional and strategic features of industrial clusters as identified by the literature such as cooperation on a strategic and socio-political level. These issues are explored in more detail below.

\section{Questionnaire}

The survey instrument used for our research consisted of 28 questions that were divided into three related sections: (i) relations with lead multinational supplier/firm; (ii) importance of cluster relations and (iii) potential for upgrading. The majority of questions had multiple choices and some asked for more details on the basis of a previous answer. It was translated into Slovak and sent to our sample of suppliers.

\section{Findings}

All of the percentages reported below represent a percentage of the firms sampled. We first asked our sample who were their main customers. The vast majority reported directly or indirectly that their main clients were foreign multinational firms based in Slovakia or abroad.

\section{(a) Characterizing the Nature of Buyer-Supplier Governance}

Figure 1 clearly illustrates the degree of dependence of the domestic automotive sector on MNE customers.

This question was followed up with issue of the dependence on one or two large clients measured as percentage of total sales. Again, as shown in Figure 2, we found a profound dependence of the local industry on one or two customers.

One of our concerns in our research was to examine the nature of contractual relations between our sample of suppliers and their customers (this refers to Table 1 which highlighted three ways of considering buyer-supplier governance) and therefore we asked about regularity of orders. The results are presented in Figure 3. 
Figure 1

Nature of Buyer-Supplier Governance

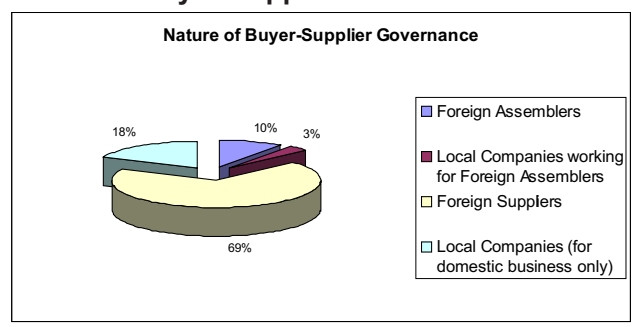

Source: Questionnaire
Figure 2

Dependance on Largest Customer

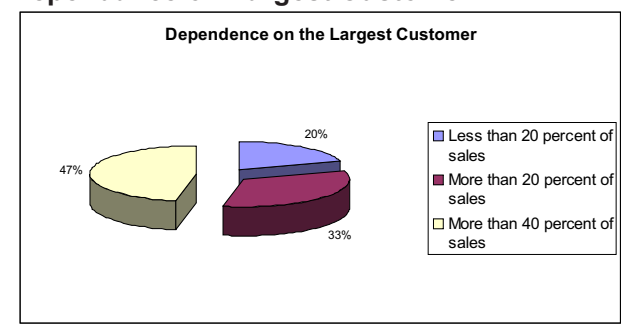

Source: Questionnaire

Our sample suppliers are for the most part involved in multiple, regular orders with almost half of the sample working on a long-term contractual basis with their customers. A corollary of this question was asked as follows:

Your customers seek the following quotations from suppliers

Multiple quotations from a number of different suppliers (based on price)

Multiple quotations from a range of existing suppliers

Exclusive quotations

Chances of winning order when quoting

Less than 25 percent $\quad 37 \%$

Less than 50 percent $\quad 33 \%$

Less than 75 percent $\quad 20 \%$

Less than 100 percent $\quad 10 \%$

The responses to the questions above reflect power relations within the GVC. While the suppliers remain heavily dependent upon a small number of customers, their clients can call upon a range of potential suppliers. It also suggests that the products sold by our suppliers face competition from substitutes and consequently implies low levels of competitive differentiation of our suppliers. As shown in Figure 4, fully three-quarters of our sample are faced with the possibility that their clients will change orders of specifications without any consultation - in fact one eighth of the sample frequently experience this with their buyers. This further reflects the relative power that MNE buyers have over their supply base.

Figure 3

Regularity of Orders

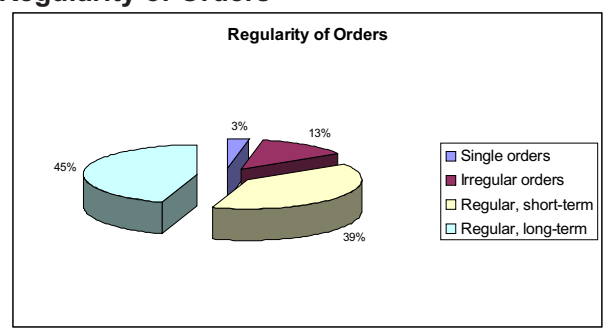

Source: Questionnaire
Figure 4

Frequency of Changes

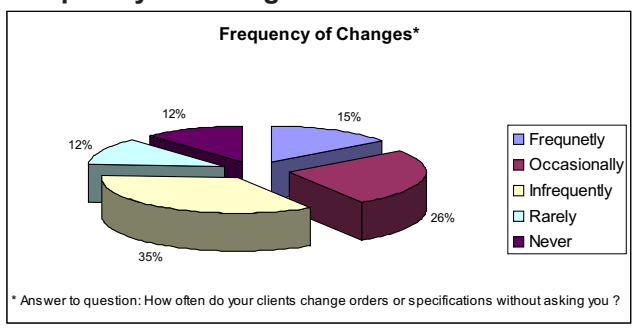

Source: Questionnaire

Next question reflects the mirror image of the buyers' power in the GVC: our supplier in sample starts production without written documentation from its clients frequently (3\%) or from time to time (15\%) and never (82\% companies). In other words, the vast majority of our suppliers in sample would not consider starting production 
without written documentation suggesting that Sako's OCR buyer-supplier relations are not present in our sample. One of the strengths of Japanese supplier-assembler relations examined in Sako's study is long-term, implicit contracting based on trust between the two parties. To the extent that suppliers rely upon the presentation of legal documents to begin production, the experience of our sample of suppliers suggests that OCR approaches are not exploited widely in Slovakia.

In the next question we asked about the extent to which clients monitor quality of samples: less than 50 percent of shipments is monitored in $22 \%$ companies, more than 50 percent of shipments in $19 \%$, and near 100 percent of shipments are monitored in $59 \%$ companies surveyed.

Proposition 2 is strengthened by this finding - that MNEs operate strong governance controls on the quality of its suppliers. Thus while they may not have fully integrated the suppliers in the Williamson vertical hierarchy, almost two-thirds of the suppliers have their samples monitored for quality.

Next question: Do you possess competencies or capabilities that your clients rely upon? revealed that $24 \%$ companies believe they have no competences or capabilities upon which their clients rely, $67 \%$ some and $9 \%$ have several. While a majority of the suppliers in sample claim that they possess competencies and capabilities, a follow up question asked them to describe in detail what these competencies were. Their responses focused on their products that they produce e.g. high quality tires rather than valuable processes or activities they may possess (the essence of core competencies). We thus express skepticism that competencies are an important part of their attractiveness to their clients.

\section{(b) Buyer-Supplier "Spillover"}

The next four questions focused on the nature of "spillover" in the buyer-supplier relations examining the nature of communication, the degree of technology transfer; the potential for intellectual property sharing as well as the possibility of human resource skills transfer through secondment opportunities.

Companies in the sample characterize communication with their clients rarely as infrequent, formal $(6 \%)$, often as frequent - both formal and informal $(50 \%)$ or very frequent, formal and informal (44\%). Technology transfer from the clients to our suppliers in sample is described as rare in 56\% cases, as from time-to-time in $38 \%$ companies and as intensive in $6 \%$. Clients provide technical specifications for orders either never (25\%) or frequently (75\%). Secondment opportunities for managers exist for our suppliers in sample rarely $(68 \%)$, sometimes $(32 \%)$, but never frequently $(0 \%)$.

Our findings paint a mixed picture for the prospects for "spillover" to the local producers. There is relatively little technology transfer between buyer and supplier with more than half of the sample reporting no technology transfer at all. Only six percent of the sample claimed intensive technology transfer between them and their clients. This is one of the main purported benefits of MNE presence in host markets - that technology will be transferred by the MNE to the local economy. Yet as proposition 2 in our paper suggests, we can infer the lack of reported technology transfer as being related to MNE strategic motivations to limit technology transfer in order to protect their competitive advantage.

In a similar fashion for our supplier sample, the rare to non-existent instances of secondment opportunities at their clients' companies suggests the limits to which managers can learn best practice through forms of 'action learning'. Womack et al. (1990) emphasized the importance of secondment opportunities for suppliers in 
building world class lean production processes in the automotive sector. This was also echoed in the Gerlach (1993) study of keiretsu groups more generally.

On the other hand, there is some evidence in our survey that there could be spillover through informal channels (rather than as part of intentional MNE strategy). Our supplier sample reports that frequent communication with their clients that is also both formal and informal. This suggests that there is a possibility to learn from their clients through business and social interaction and observation.

This finding is further strengthened by the fact that two-thirds of the sample report that they receive technical specifications for their orders from clients. Receiving these specifications, some of which could be in the form of blueprints, may allow suppliers to learn about the use for their production in downstream assembly. And while reverse engineering of processes and products may have ethical implications, the experience of South Korean and Japanese companies in the past suggests that this can provide an opportunity for suppliers to learn to develop competitive products.

\section{(c) Supplier Upgrading}

The following questions sought to evaluate the degree of supplier industrial upgrading as a consequence of their relationship with their clients. Our questions focused on structural (technology) and strategic (e.g. marketing, internationalization and product development) aspects of industrial upgrading.

Extent in which our supplier in sample has upgraded its technology base as a consequence of its relationship with its clients:

$\begin{array}{lr}\text { Hardly } & 0 \% \\ \text { To some extent } & 45 \% \\ \text { A lot } & 55 \%\end{array}$

Extent in which our sample's clients allow them to sell to their clients' competitors:

Never

Sometimes

$50 \%$

No restriction $\quad 50 \%$

Degree in which our suppliers in sample will be able to sell their products to new clients in the future:

$\begin{array}{ll}\text { Unlikely } & 40 \% \\ \text { Likely } & 20 \% \\ \text { Definitely } & 40 \%\end{array}$

Extent in which our sample firms have been able to improve their marketing strategy as a consequence of their relationships with their clients:

$\begin{array}{lr}\text { Hardly } & 3 \% \\ \text { To some extent } & 64 \% \\ \text { A lot } & 33 \%\end{array}$

\begin{tabular}{lc}
\multicolumn{2}{c}{ Prospects for international export of your products: } \\
Bad & $3 \%$ \\
Neutral & $23 \%$ \\
Good & $42 \%$ \\
Excellent & $32 \%$
\end{tabular}

On a structural level, having MNE clients has required the suppliers in our sample to upgrade their technology. This should not be much of a surprising finding - especially since some of the firms in our sample operated before 1989 and as part of the transition process were expected to upgrade their technology. It would be a necessary but not sufficient condition for winning contracts.

On a strategic level, having a relationship with an MNE buyer means that only half of the supplier sample is allowed to sell to competitor firms of the MNE. Nevertheless, sixty percent of our supplier sample believes that they will be able to sell to new 
companies in the future. It can be inferred that they perceive potential competitive advantage from their experience of serving MNEs. As for marketing strategy, one third of our sample believe that their MNE relationships have improved their ability to market their products significantly, while almost two thirds believe that they have improved to some extent. Being able to market their products effectively is a sign of strategic upgrading that raises the competitiveness of firms in their relevant market. Also since marketing is a "support" activity in the GVC and can become a core competence, it may also enable firms to enter new markets and offer new products and services, e.g. to become a first-tier supplier in the automotive GVC. Lastly, as regards export strategy, our suppliers in sample are optimistic about their prospects for exporting their products - only a quarter of our sample are neutral or pessimistic about future export opportunities with almost one third regarding export possibilities as excellent. Again, ability to successfully export and more specifically the development of export competitiveness is a useful leading indicator for general competitiveness.

\section{(d) The Extent of Clustering of Local Suppliers}

The last set of questions for our survey examined the extent to which the geographically proximate group of suppliers in Slovakia displayed attributes of being an industrial cluster as identified in the cluster literature. We focused our questions on a number of aspects of clustering, notably, the presence of formal institutions that promote cooperation; the role of public policy lobbying; knowledge sharing among competitor firms; communications among firms; the importance of the skilled workers in the local labour market and the degree of strategic cooperation among firms.

In our sample significance of local trade and industry associations was none in $26 \%$, limited in $61 \%$ and considerable in $13 \%$ of surveyed companies. Extent of joint lobbying activities with other firms in the locality was described as none in $68 \%$ companies, occasional in $29 \%$, and frequent just in 3\% companies.

Extent of collaboration/cooperation with actual/potential competitors is shown in the Table 2.

Table 2

Collaboration/Cooperation with Actual/Potential Competitors

\begin{tabular}{|l|c|c|c|c|c|}
\hline & Not at all & Rarely & Sometimes & Often & Total \\
\hline $\begin{array}{l}\text { Extent of Collaboration/Cooperation with } \\
\text { Actual/Potential Competitors in } \\
\text { Knowledge Sharing/Management }\end{array}$ & 35 & 45 & 20 & 0 & $\mathbf{1 0 0}$ \\
\hline $\begin{array}{l}\text { Extent of Collaboration/Cooperation with } \\
\text { Actual/Potential Competitors in Export } \\
\text { Promotion }\end{array}$ & 67 & 23 & 10 & 0 & $\mathbf{1 0 0}$ \\
\hline $\begin{array}{l}\text { Extent of Collaboration/Cooperation with } \\
\text { Actual/Potential Competitors in Joint } \\
\text { Investment in Infrastructure }\end{array}$ & 94 & 0 & 3 & 3 & $\mathbf{1 0 0}$ \\
\hline
\end{tabular}

Source: Questionnaire

Next question about the extent in which our supplier in sample benefits from a local pool of skilled labour revealed that $45 \%$ companies often benefit from it, $49 \%$ companies sometimes, $6 \%$ companies rarely, and $0 \%$ companies never. Communications/relations with competitors in the locality was described as weak in $21 \%$ cases, neutral in $57 \%$, cordial in $18 \%$ and strong in $4 \%$. With the exception of a local market for skilled workers, our supplier sample displayed few of the attributes of a cluster as identified in the extant literature. 
Neither formal institutions in the form of trade or industry associations nor active lobby of public policymakers registered importance for our supplier sample. Only a limited role for associations and an even smaller role for lobbying were present in the sample's responses. This suggests that one of the necessary conditions for successful cluster formation - the creation of functioning institutions external to the firm but internal to the market is not present in Slovakia.

On a strategic level, our supplier sample demonstrated low recognition of the potential for cooperation among competitors. Only one-fifth of the sample cooperated in knowledge management/sharing; a tenth cooperated in export promotion and only 3 percent of our sample invested in joint infrastructure. Recognition of the importance of strategic cooperation and a deliberate attempt to capture potential external economies of scale and scope from cooperation are not present in our sample survey. These latter features are hallmarks of a functioning industrial cluster according the literature. Lastly, communications between firms in our sample is at best neutral with 57 percent reporting this. And one-fifth of the sample reported weak communications between firms in the locality. Overall, the strategic atomization of the firms in the locality is stark and has significant strategic and public policy implications, which we turn to in our conclusion. The origins and ownership of our company sample may help explain some of these outcomes. One of the reasons for the non-existence of a typical cluster could be attributed to ownership differences among the studied companies - some of them are local companies - formerly stated-owned, later privatized by local entrepreneurs, some of them have been privatized by foreign companies from different foreign countries, some of them are "relatively new" greenfields coming as a result of the activity of their big customer.

\section{Concluding Remarks and Implications for Future Research}

In examining the Slovak automotive supplier industry, we were conceptually and empirically attempting to draw together extant and related literature: work on the governance of GVCs; research on host country "spillovers" as a consequence of MNE activity and the broader cluster and innovation literature. While cluster research had done important work in identifying and operationalizing the necessary conditions for cluster formation, it had relatively ignored the global-local linkage brought by the presence of MNEs. The "spillover" literature has identified in theory numerous potential benefits of MNE presence in host countries there was relatively little empirical work in CEE done to discover if these benefits actually exist in practice. Neither literature had focused on how MNEs govern their GVCs. Thus bringing the available literature together presented an important analytical opportunity for the field of international business.

We find that in the Slovak case, aside from geographical proximity, the industrial clusters among the firms surveyed were not much functional. On a strategic level, there appears to be little evidence of cooperation in the areas of marketing, export promotion or investment. This is especially of concern in sectors such as automotive where cooperative strategies among suppliers could offer significant benefits.

We also find that MNEs appear to maintain tight control over their relations with their suppliers with little technology transfer restraining their options who their suppliers can sell to and restricting the use of multiple company tendering. An analysis of power relations between suppliers and their clients suggests that significant bargaining power resides in the hands of the buyers. In Humphrey and Schmitz's framework, the MNEs exercise a form of quasi-hierarchy, adopting forms of arms-length relationships (e.g. multiple price quotations) and technical information exchange (e.g. order specifications) and contractual restrictions. In fact, from the 
strategic perspective of an MNE, this is the optimal balance between market driven and internalized benefits. Yet from the perspective of local suppliers, this places substantial constraints on their abilities to industrially upgrade.

Of concern also is the observation by the suppliers that there is little intentional technology transfer from the MNEs to the suppliers. This undermines one of the main public policy arguments in favour of host governments encouraging foreign direct investment and suggests that in the Slovak automotive case at least, the technological "spillover" may be limited.

Future areas of research could focus on similar studies for neighbouring countries such as the Czech Republic, Hungary, Poland and Romania all of whom have received significant foreign direct investment in the automotive sector in recent years and who have developed a supplier base for global automotive assemblers and suppliers. For example, are there different institutional and structural aspects of the firms in these countries that may allow them to develop cluster activity? Would cooperation among firms in clusters change the nature of governance of GVCs? Does cooperation among firms in the automotive supply chain enhance the potential for industrial upgrading?

\section{References}

Akbar, Y. (2003), The Multinational Enterprise and EU Enlargement: The Effects of Regulatory Convergence. London : Palgrave.

Akbar, Y., Elms, H., Tej Dhakar (2006), "Investigating the contribution of Foreign Direct Investment and Stock Exchange Development to Economic Development in East and Central Europe: A Preliminary Analysis." Forthcoming in International Finance Review.

Akbar, Y., McBride, B. (2004), "Multinational Enterprise Strategy, Foreign Direct Investment and Economic Development: The Case of Hungary." Journal of World Business, 39, pp. 89-105.

Antal-Mokos, Z. (1998), Privatisation, Politics and Economic Performance in Hungary. Cambridge : Cambridge University Press.

Bair, J., Gereffi, G. (2001), "Local Clusters in Global Chains: The Causes and Consequences of Export Dynamism in Torreon's Blue Jeans Industry." World Development, 29 (11), pp. 1885-1903.

Baláž, P. (2004), "Postavenie fúzií a akvizícií v globalizácii svetového hospodárstva." Politická ekonomie, (4), pp. 485-502.

Bathelt, H., Malmberg, A., Maskell, P. (2002), "Clusters and knowledge: local buzz, global pipelines and the process of knowledge creation." DRUID Working Paper No. 02-12, Copenhagen.

Bevan, A., Estrin, S. (2000), "The Determinants of Foreign Direct Investment in Transition Economies." Williams Davidson Institute Working Paper 342.

Blomström, M., Sjoholm, F. (1999), "Technology Transfer and Spillovers: Does Local Participation with Multinationals Matter?" European Economic Review, 43 (4), pp. 915-923.

Breschi, S., Malerba, F. (2001), "The geography of innovation and economic clustering: some introductory notes." Industrial and Corporate Change, 10 (4), pp. 817-833.

Bridgewater et al. (1995), "Strategic Investment Decisions by Western Firms in Ukraine: The Role of Relationships in Home and Host Market Networks." Journal of East West Business, 1 (3), pp. $17-35$.

Brouthers et al. (1998), "Central and Eastern European Investment: A Comparison of US, Dutch and German Firms' Activities," in Hooley et al., eds., Internationalization: Process, Contexts and Markets. MacMillan Press.

Cook, P., Uranga, M.G., Etxebarria, G. (1997), "Regional innovation systems: institutional and organizational dimensions." Research Policy, 26 (4), pp. 475-491.

Estrin, S., Hughes, K., Todd, S. (1997), Foreign Direct Investment in Central and Eastern Europe: Multinationals in Transition. London and Washington, DC : Pinter.

Estrin, S., Richet, X., Brada, J.C., eds. (2000), Foreign Direct Investment in Central Eastern Europe: Case Studies of Firms in transition. London : M.E. Sharpe.

Fabry, N.H. (2001), "The Role of Inward-FDI in the Transition Countries of Europe: an Analytical Framework." Current Politics and Economics of Russia, Eastern and Central Europe, 16 (3), pp. 349-77.

Ferenčíková, S., Dudáš, T. (2005), 'Vplyv prílevu priamych zahraničných investícií na hospodársky rast $v$ nových členských štátoch Európskej únie zo strednej a z východnej Európy." Ekonomický časopis, 53 (3), pp. 261-272.

Ferenčíková, S., Fifeková, M. (2006), "FDI spillovers in Slovakia - Trends from the Last decade and Recent Evidence from Automotive Industry." Ekonomický časopis, 54 (7), pp. 633-651. 
Hendry, C., Brown, J., DeFillipi, R. (2000), "Regional clustering of high-technology-based firms: opto-electronics in three countries." Regional Studies, 34 (2), pp. 129-144.

Humphrey, J., Schmitz, H. (2001), "Governance in global value chains." IDS Bulletin, 32 (3), pp. 19-23. (2002), "How does insertion in global value chains affect upgrading in industrial clusters?" Regional Studies, $36(5)$, pp. 1017-27.

Hunya, G. (2000a), "Central Europe Catching-up Through FDI?" in Hunya, G., ed., Integration Through Foreign Direct Investment: Making Central European Industries Competitive. Cheltenham and Northampton : Edward Elgar, pp. 8-27.

Hunya, G. (2000b), "International Competitiveness Impacts of FDI in CEECs." The Vienna Institute for International Economic Studies No. 268, August. Vienna.

Gereffi, G. (1994), "The organization of buyer-driven global commodity chains: how US retailers shape overseas production networks," in Gereffi, G., Korzeniewicz, M., eds., Commodity Chains and Global Capitalism. New York : Praeger, pp. 95-122.

(1999), "International Trade and Industrial Upgrading in the Apparel Commodity Chain." Journal of International Economics, 48 (1), pp. 37-70.

Gerlach, M. (1993), Alliance Capitalism: The Social Organization of Japanese Business. Berkeley : University of California Press.

Kenney, M., ed. (2000a), Understanding Silicon Valley: The Anatomy of an Entrepreneurial Region. Stanford, CA : Stanford University Press.

Konings, J. (2001), "The effects of foreign direct investment on domestic firms: Evidence from firm-level panel data in emerging economies." Economics of Transition, 9 (3), pp. 619-34.

Krugman, P. (1991), Geography and Trade. Cambridge, MA : MIT Press.

Martin, R., Sunley, P. (2003), "Deconstructing clusters: chaotic concept or policy panacea?" Journal of Economic Geography, 3 (1), pp. 5-35.

Marshall, A. (1890), Principles of Economics. London : Macmillan.

Meyer, K. (1998), Direct Investment in Economies in Transition. Cheltenham : Edgar Elgar.

Mogyorosiová, Z., Báráňová-Čiderová, D. (2005), "Predpoklady napĺňania podmienok členstva v EÚ zo strany SR a ČR." Ekonomické rozhl'ady, 53 (3), pp. 391-399.

Palpacuer, F., Parisotto, A. (2003), "Global Production and Local Jobs: Can Global Enterprise Networks be Used as Levers of Economic Development?" Global Networks, 3 (2), pp. 97-120.

Pavlínek, P. (2003), "Alternative Theoretical Approaches to Post-Communist Transformations in Central and Eastern Europe." Acta Slavica laponica, 20 (1), pp. 85-108.

Plikynas, D., Akbar, Y.H. (2006), "Explaining FDI Patterns in East and Central Europe: A Neural Network Approach." Forthcoming in Eastern European Economics.

Porter, M. (2003), "The economic performance of regions." Regional Studies, 37 (6), pp. 549-578. "Clusters and Competition: new agendas for companies, governments, and institutions," in Porter, M., ed., On Competition. Cambridge, MA : Harvard Business Review Books, pp. 197-287. (1990), The Competitive Advantage of Nations. New York : Free Press.

Pouder, W., St. John, W. (1996), "Hot Spots and Blind Spots: Geographical Clusters of Firms and Innovation." Academy of Management Review, 24 (4), pp. 1192-1225.

Pye, R. (1998), "Foreign Direct Investment in Central Europe, Experiences of Major Western Investors." European Management Journal, 16 (4), pp. 378-389.

Sako, M. (1992), Prices, Quality and Trust. Cambridge : Cambridge University Press.

Saxenian, A. (1994), Regional Advantage: Culture and Competition in Silicon Valley and Route 128. Cambridge, MA : Harvard University Press.

Schlie, E.H., Yip, G.S. (2000), „Regional Follows Global: Strategy Mixes in the World Automotive Industry." European Management Journal, 18 (4), pp. 343-354.

Scott, A.J. (1996), "Regional motors of the global economy." Futures, 28 (4), pp. 391-411.

Sturgeon T.J. (2003), "What really goes on in Silicon Valley: Spatial clustering and dispersal in modular production networks." Journal of Economic Geography, 3 (3), pp. 199-225.

Szanyi, M. (2000), "The Role of FDI in Restructuring and Modernization: an Overview of Literature," in Hunya, G., ed., Integration Through Foreign Direct Investment: Making Central European Industries Competitive. Cheltenham and Northampton : Edward Elgar, pp. 50-80.

Tihanyi, L., Roath, A.S. (2002), "Technology Transfer and Institutional Development in Central and Eastern Europe." Journal of World Business, 37 (3), pp. 188-198.

Williamson, O. (1979), "Transaction-Cost Economics: The Governance of Contractural Relations." Journal of Law and Economics, 22 (2), pp. 233-61.

Wolfe, D., Gertler, M. (2004), "Clusters from the Inside and Out: Local Dynamics and Global Linkages." Urban Studies, 41 (5/6), pp. 1071-1093.

Womack, J., Jones, D.T., Roos, D. (1990), The Machine that Changed the World: Based on the Massachusetts Institute of Technology 5-Million-Dollar 5-Year Study on the Future of the Automobile. New York: Scribner.

Zemplinerová, A. (1998), "Impact of Foreign Direct Investment on the Restructuring and Growth in Manufacturing." Prague Economic Papers, 7, pp. 329-45.

Žižka, M. (2006), "Klastry jako nástroj zvyšování konkurenceschopnosti podniku a regionu. (Clusters as a Tool for Increasing Competitiveness of Enterprises and Regions)." Inaugural Dissertation, Liberec : Technická univerzita. 